\title{
Occurrence of Spirocerca Iupi Infection in Hungarian Dogs Referred for Gastroscopy
}

Roland Psáder ${ }^{\circledR} \bowtie$, Márton Balogh1, Kinga Pápa1, Ágnes Sterczer', Zoltán Lukács², Andrea Harnos ${ }^{3}$

1 Department and Clinic of Internal Medicine, University of Veterinary Medicine, 1078 Budapest, Hungary

2 Bayer Hungária Kft., 1123 Budapest, Hungary

${ }^{3}$ Department of Biomathematics and Informatics, University of Veterinary Science, 1078 Budapest, Hungary

\section{Corresponding author:}

\section{Roland Psáder}

E-mail: Psader.Roland@univet.hu

\section{Abstract}

The nematode Spirocerca lupi (Rudolphi 1809) is widely distributed, classically causing parasitic nodules in the esophagus, aortic aneurysms and spondylitis. Clinical signs of infection are regurgitation, vomiting, weight loss, coughing, dyspnea and, rarely, sudden death. This retrospective study (2007-2016) investigated the prevalence and treatment outcome of Hungarian dogs with esophageal spirocercosis presented at the Endoscope Laboratory of the University of Veterinary Medicine Budapest (ELUVMBP). The change in the annual number of cases/upper gastrointestinal endoscopies (UGIE) and cases/ total number of endoscopies (TNE, the entire case load of ELUVMBP), and the efficacy of different treatment methods were examined. In the time period mentioned above, a total of 30 patients referred for UGIE were diagnosed with spirocercosis. The annual case numbers significantly increased in comparison to both the number of UGIEs $(P=0.0085)$ and TNEs $(P=0.0096)$. The annual distribution of cases does not differ significantly from an even distribution $(\mathrm{P}=0.1589)$. Our study showed a significant increase in the number 
of cases with spirocercosis in Hungary between 2007 and 2016, and this this disease is prevalent at all times of year.

\section{Introduction}

Spirocercosis is caused by the worm Spirocerca lupi (Chitwood 1934). The majority of case reports are from South Africa (Lobetti 2000), Israel (MazakiTovi et al. 2002, Aroch et al. 2015) and Greece (Mylonakis et al. 2001), but the disease has been reported in Hungary (Bokori 1956, Széll et al. 2001) as well. The dogs are infected via ingestion of coprophagic beetles, or their avian or small reptile predators. The migrating larvae cause hemorrhages, endarteritis, aortal stenosis, aneurysm or aortal rupture, which result in vomiting, inappetence or even sudden death due to damage to the aorta. Connective tissue nodules form at the final site of adult worms, most commonly in the esophagus but occasionally in the wall of the stomach as well. Because of these nodules, the patients show signs of retching, vomiting, regurgitation, weight loss and aspiration. Further symptoms include fever, labored breathing, lethargy, melena, paraparesis, spondylitis of the caudal thoracic vertebrae and hypertrophic osteopathy. Due to larval migration, nodules or granulomas can form in locations other than the stomach and the esophagus (thoracic organs, intestinal tract, urinary organs, connective tissue of the skin) (Széll et al. 2001, Kassai 2011, Lobetti 2013). Sarcoma can develop from the granulomas (Bailey et al. 1963, Ranen et al. 2004). Salivary gland necrosis has also been reported in association with S. lupi infection (Schroeder and Berry 1998). Esophagoscopy provides an opportunity to identify the typical nodules caused by the parasite, whereas a differentiation between granulomas and sarcomas can be achieved by histopathologic evaluation of biopsy samples (Willard 2013). With endoscopy, we can make the diagnosis before egg shedding commences. In the literature the sensitivity of esophagoscopy varies between $87.1 \%$ (Aroch et al.
2015) and 100\% (Mazaki-Tovi et al. 2002) (depending on the actual study) compared to the $14 \%$ (Lobetti 2000) and 80\% (Mazaki-Tovi et al. 2002) sensitivity of fecal flotation, and the $53 \%$ (MazakiTovi et al. 2002) sensitivity of thoracic radiography. Diethyl-carbamazine treatment reduces clinical signs and egg shedding, although it is not effective against adult worms (Lobetti 2013). Ivermectin can be used to treat spirocercosis according to several publications, although recommendations regarding the dose and time of treatment vary between authors. Ivermectin injections $(600 \mu \mathrm{g} / \mathrm{kg}$ s.c. twice per week) combined with oral prednisone $(0.25 \mathrm{mg} /$ $\mathrm{kg} \mathrm{q} 12$, then lowering the dose every two weeks) cause regression of nodules in 5 out of 8 naturally infected dogs (Mylonakis et al. 2004). Based on literature data, doramectin can be applied to treat spirocercosis with good clinical efficacy (Lobetti 2013). There are multiple recommendations regarding dose and time of treatment with doramectin according to studies and the clinical experience of the various authors: $400 \mu \mathrm{g} / \mathrm{kg}$ s.c. injection every 14 days $6 \mathrm{x}$ (Lavy et al. 2002), $500 \mu \mathrm{g} / \mathrm{kg}$ p.o. daily for six weeks (Lobetti 2013). The toxicity of ivermectin and doramectin is breed-specific, mainly occurring in collies and other English shepherd dogs, although it has been reported in other breeds as well. The toxicity depends on the mutation of the MDR-1 $\Delta$ gene and the expression of protective glycoprotein P (Lobetti 2013). Milbemycin oxime, applied at $0.5 \mathrm{mg} / \mathrm{kg}$ for 28 days (Beugnet et al. 2016, Kok et al. 2010, 2011), or spot-ons containing a combination of imidacloprid and moxidectin are both confirmed as being suitable for spirocercosis prevention (Austin et al. 2013, Le Sueur et al. 2010). Although the esophageal granulomas caused by Spirocerca lupi can be successfully treated with doramectin, sarcomas require surgical and oncological treatment (Willard 2013).

In our retrospective study, we examined the local presence of spirocercosis in dogs arriving for esophageal and gastric endoscopy at the ELUVMBP between January 1, 2007 and September 30, 2016. 


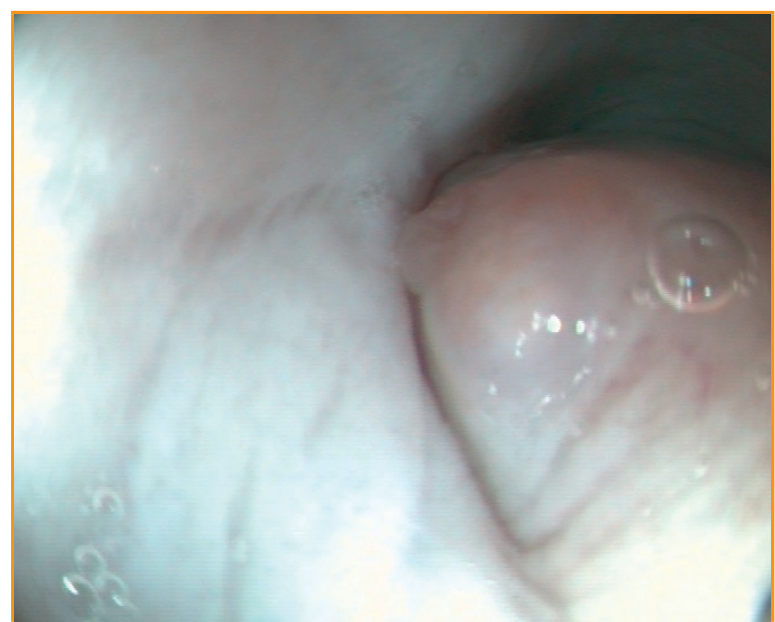

Fig. 1 Endoscopic appearance of a Spirocerca lupiinduced granuloma of the esophagus in a dog

\section{Materials and methods}

Endoscopic diagnosis of canine spirocercosis We used a Karl Storz 60914 PKS (Karl Storz Company, Germany) flexible video endoscope $(9.7 \mathrm{~mm}$ sheath, $140 \mathrm{~cm}$ length, $2.8 \mathrm{~mm}$ working channel diameter) to conduct the endoscopic examinations. All patients were examined under general anesthesia. The examination included esophagoscopy and gastroscopy as well. The diagnosis was made based on the characteristic endoscopic appearance of the esophagus (Fig. 1) or the surgical and histopathological evaluation of the mass causing the obstruction (Fig. 2).

\section{Data collection}

Data for the study was provided by spirocercosis diagnoses made at ELUVMBP between January 1, 2007 and September 30, 2016. The data needed for our study was collected from the electronic register of the Small Animal Clinic. Consultations with the referring veterinarian or the owner were also conducted for further data acquisition.

\section{Statistical evaluation}

Bar graphs were used to demonstrate case numbers. The annual case/UGIE and annual case /TGE

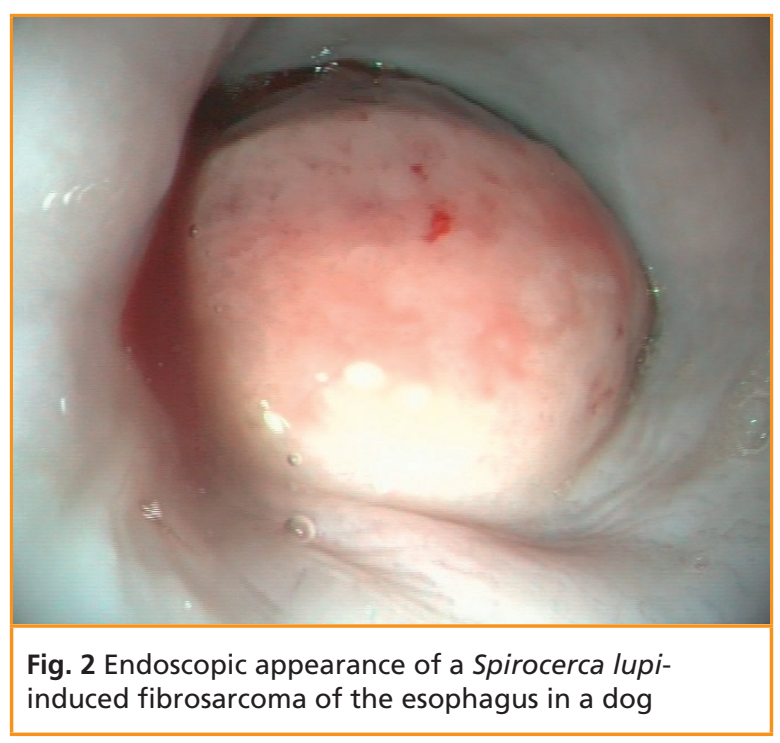

count were examined using linear regression fitted by generalized least square estimation method, assuming first degree autoregressive correlation between the annual data. The Chi square test was used to compare the distribution of case numbers. $\mathrm{P}$ values were calculated using a Monte Carlo simulation due to the low expected case numbers.

\section{Results}

\section{Case numbers}

Altogether 30 patients (arriving for endoscopic examination between January 1, 2007 and September 30,2016 ) were diagnosed with spirocercosis. The yearly distribution of case numbers varied between 0 and 8, with 2007 being the year with the least (0) cases, whereas 2015 being the year with the most diagnoses (8) (Fig. 3).

We evaluated the abundance of spirocercosis cases during our statistical analysis in relation to the amount of UGIEs and total (respiratory, gastrointestinal and urinary) endoscopies in the Endoscopic Laboratory, which increased over the examined time period. The case numbers significantly increased compared to both the UGIEs $(\mathrm{P}=0.0085)$ (Fig. 4) and the TGEs (P=0.0096) (Fig. 5). 


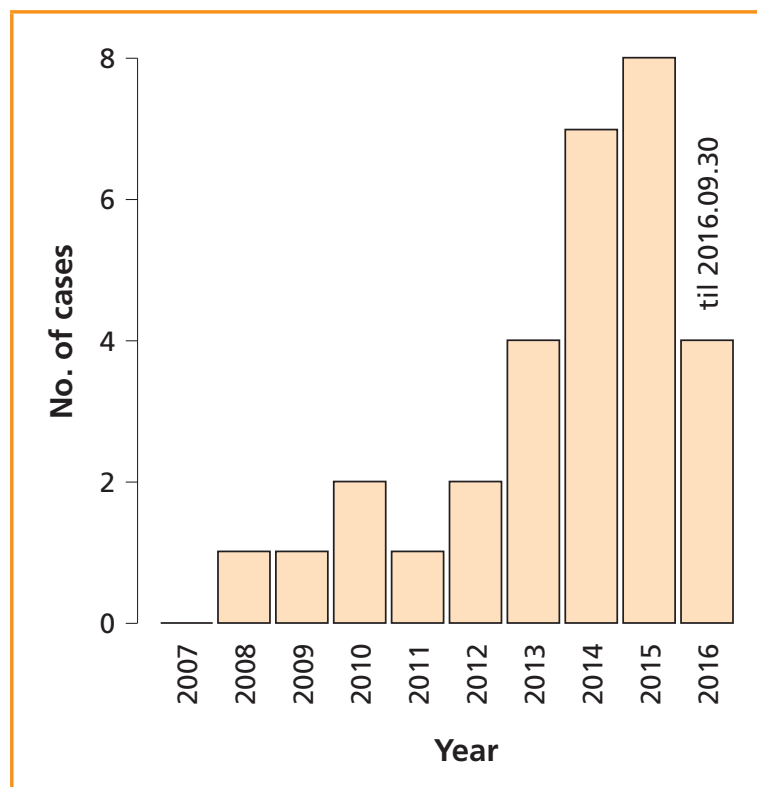

Fig. 3 The annual incidence of spirocercosis at the ELUVMBP between January 1, 2007 and September 30, 2016
We also examined the monthly distribution of the cases (Fig. 6) and if the treatment method (surgical or conservative treatment) and the outcome (remission or no remission) depended on the time of endoscopic diagnosis (in which month the diagnosis was made). The monthly distribution of cases with remission can be seen on Fig. 7 .

The yearly distribution of cases does not significantly differ from uniform ( $\mathrm{P}=0.1589)$, the same is true for cases with conservative treatment $(\mathrm{P}=0.1494)$ and remission $(\mathrm{P}=0.4678)$.

\section{Geographical distribution of cases}

The patients originated from a total of 17 Hungarian cities. 10/30 (33.33\%) from Budapest, 2/30 (6.67\%) from Gyál, and 4/10 (13.33\%) from Kecskemét. The rest of the cases arrived from Bonyhád, Debrecen, Érd, Erdőkertes, Fót, Göd, Gödöllő, Gyúró, Kerepes, Kiskunhalas, Maglód, Sülysáp, Sződ and Törökbálint (1 from each) (Fig. 8). In a county-based distribution, most cases originated from Pest county $(12 / 30,40 \%)$, followed by the

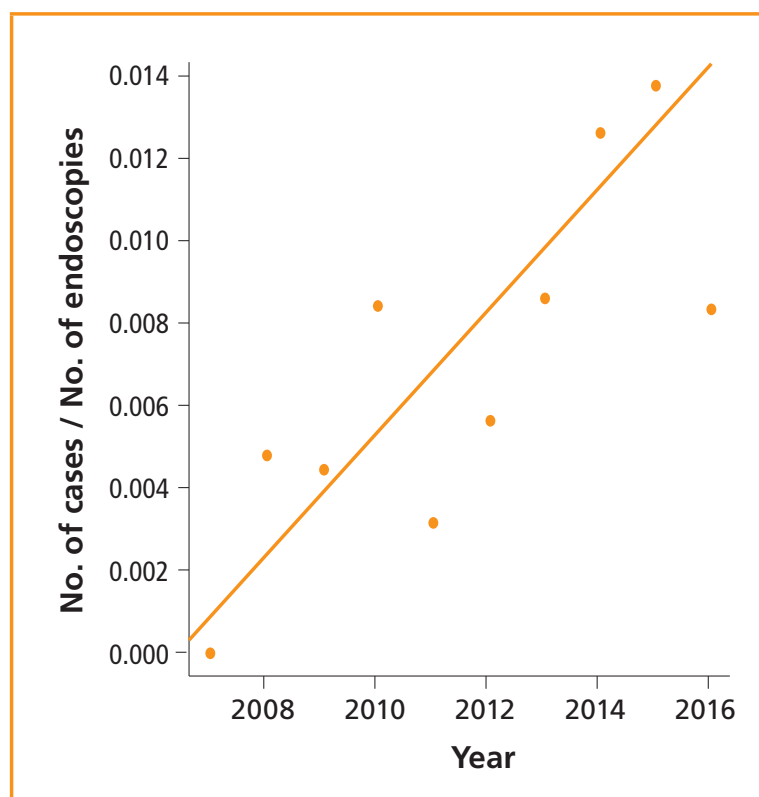

Fig. 4 Changes in the ratio between the number of dogs with spirocercosis and number of endoscopic cases at the ELUVMBP during 2007-2016

capital, Budapest, and then Bács-Kiskun county $(5 / 30,16.67 \%)$.

\section{Therapy and outcome}

Conservative treatment was given in 19 out of 30 patients and 4 underwent surgical management. We do not have data on 5 patients, and no treatment was started in 2.20 out of the 30 patients are confirmed to be symptom-free; of these, 17 received conservative treatment and 3 underwent surgery. 13 out of the 19 patients undergoing conservative treatment received doramectin, 11 of these are confirmed to be symptom-free, and we do not have data from the other 2 (the owners did not return for treatment). The 6 remaining patients undergoing conservative treatment received imidacloprid/moxidectin, milbemycin oxime, ivermectin or a combination of these. 2 out of the 30 patients are known to have been put down because of spirocercosis (one a week after the surgery, because of relapse of symptoms, the other without treatment), but we have no data on further deaths. 


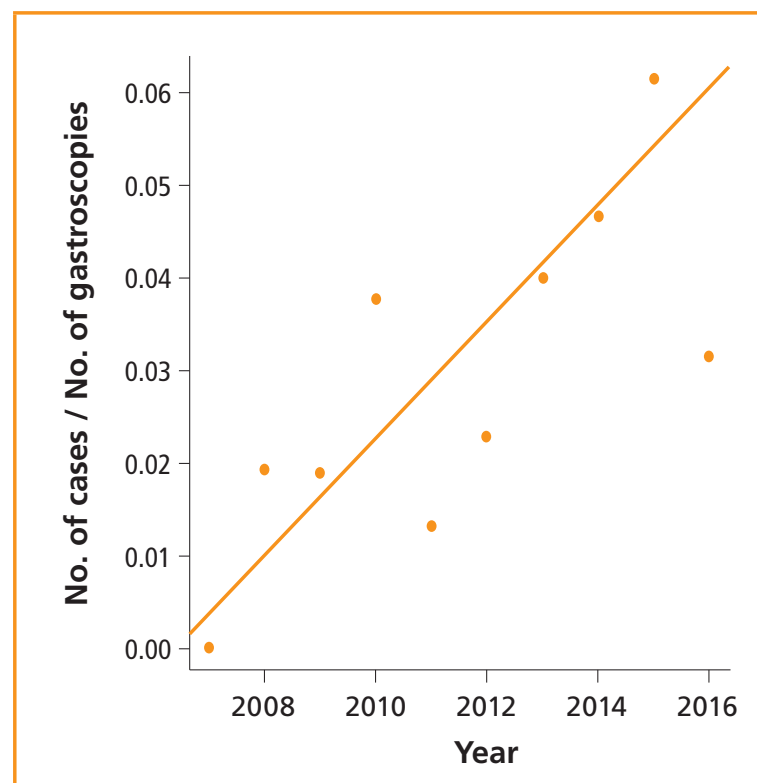

Fig. 5 Changes in the ratio between the number of dogs with spirocercosis and the number of gastroscopic cases at the ELUVMBP during 2007-2016

\section{Discussion}

Based on our study, the increase in the frequency of positive cases is clearly related to the spread of spirocercosis in Hungary. We already had literature data about canine spirocercosis. The first case description, from a clinical case load, originates from 1956, from an approximately 10 -year-old Puli dog. The patient arrived at the Clinic of Internal Medicine of the Veterinary University with a twoweek history of lethargy, reduced movement and retching. The patient's appetite had reduced to a liquid diet. The diagnosis was based on the necropsy ("the $5 \mathrm{~cm}$-long part of the esophagus immediately before the diaphragm has a nodular surface and is firm on palpation. The lumen of the esophagus is narrowed and reduced in flexibility, can only be penetrated by a probe with the diameter of a pencil") (Bokori 1956). Széll et al. (2001) described two cases in 2001, one of them was diagnosed by autopsy, the other by Sheather flotation. So far, no study has been conducted with such a case load in Hungary. Although the number of small animal

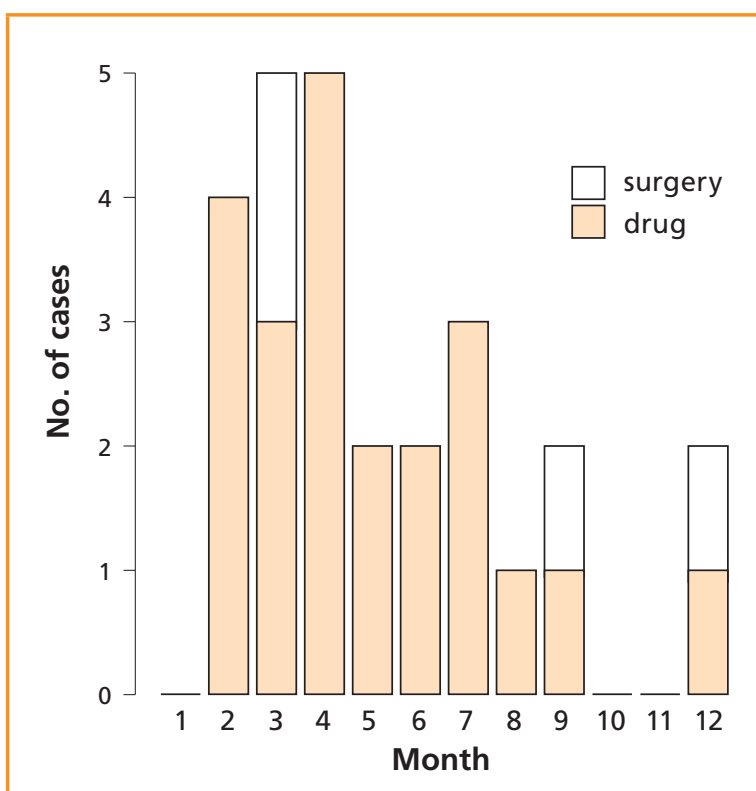

Fig. 6 Monthly incidence of dogs with spirocercosis during 2007-2016

specialists is constantly increasing, and diagnostic methods-including the increasing popularity of endoscopic examinations - are constantly improving, this is not leading to a significant increase in case numbers. Since the number of patients arriving for gastroscopy and endoscopy at the Small Animal Clinic has increased constantly, this factor was taken into account during the statistical evaluation of the data. A similar increase has been reported in Israel (Mazaki-Tovi et al. 2002, Aroch et al. 2015), where urbanization, global warming, increased frequency of animal travel and an increase in dung beetle vectors were associated with the problem. The distribution of diagnosed spirocercosis cases has been even, but we did not see seasonality, suggesting that this disease may be encountered at any time of year. The treatment method and the outcome of the disease did not depend on the time of endoscopic diagnosis. This can be explained by the long prepatent period of the parasite, the number of chronic cases and climate change, due to which the vector beetles are accessible for both dogs and paratenic hosts for most of the year. Mazaki-Tovi 


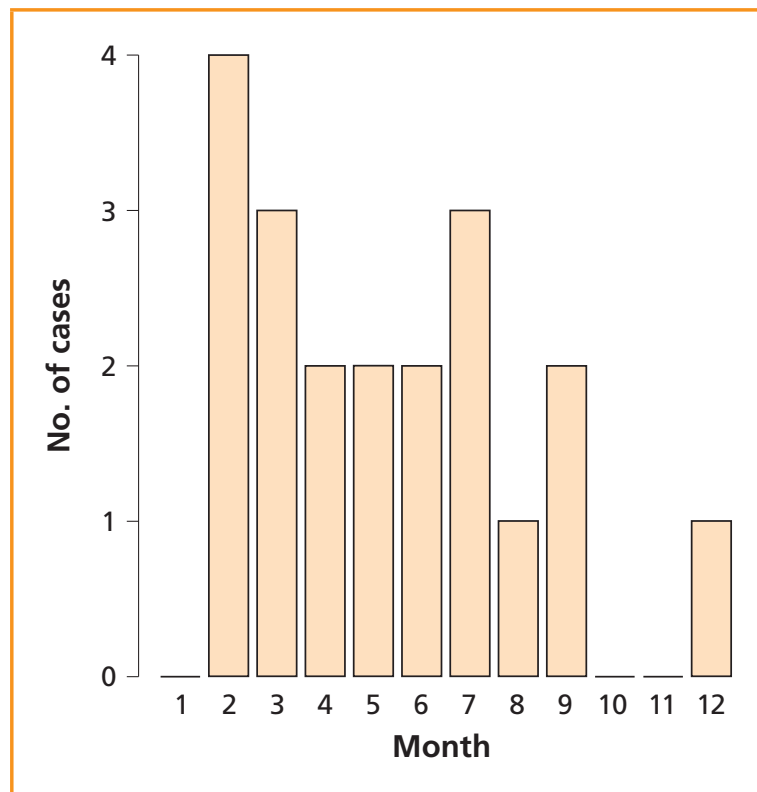

Fig. 7 Monthly distribution of cured dogs during 2007-2016 et al. (2002) discovered a clear seasonality in their study of the period between 1991 and 1999, as most of their diagnoses were made in December to April (cold months), explained by the biology of vectors and the six-month pathogenesis. In a later study, the same research team-by examining the spirocercosis cases between 2004 and 2009-found that, similarly to our results, there is no visible statistical difference in the monthly distribution of cases. This leads to the conclusion that the disease has become endemic in the examined area (Aroch et al. 2015).

During the time frame of the study, more than twothirds of the Hungarian Spirocerca lupi cases were diagnosed in Budapest and surrounding (73.3\%). After this area, Bács-Kiskun county seemed the most infected. In our study we did not look at patient referral customs in the different counties,

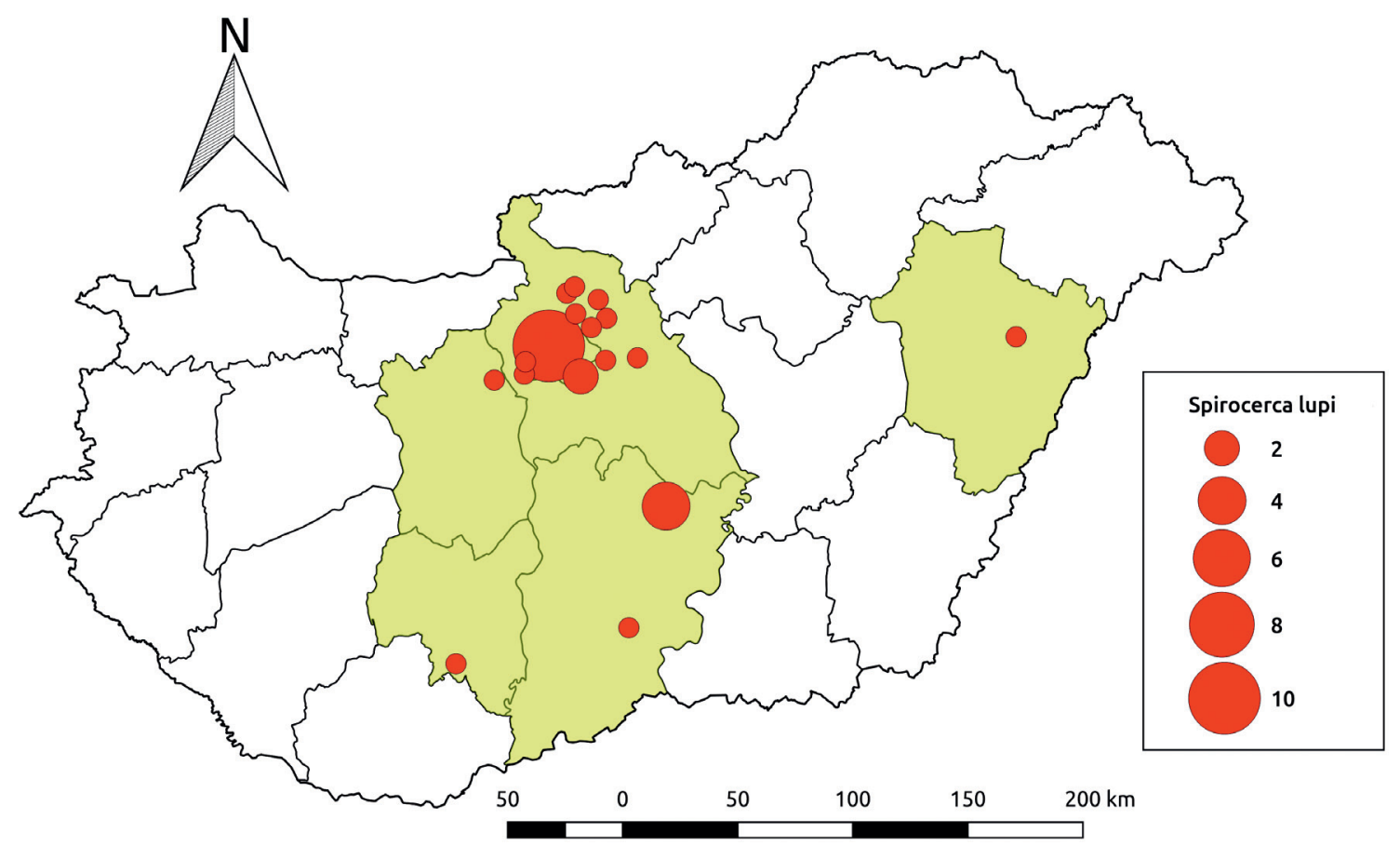

Fig. 8 The geographic distribution in Hungary of the dogs diagnosed with spirocercosis during 2007-2016 
or how the prevalence of the disease relates to the total number of endoscopic referrals per city. These aspects require further research. In the previous study in Israel, spirocercosis was present in greater numbers in urban dogs (Mazaki-Tovi et al. 2002). However, this difference between urban and rural environments could not be detected in later research (Aroch et al. 2015). In South Africa and Kenya, the disease was more prevalent in the countryside, mainly in stray dogs (Fitzsimmons 1960, Brodey et al. 1977, Evans 1983). Literature data suggest-the distribution of immediate and paratenic hosts as the biggest factor affecting the occurrence of the disease (Lobetti 2000), and the presence of these species in Hungary should therefore be investigated in future research.

Due to the retrospective nature of our study, and our clinic being a referral clinic, our data regarding treatment is incomplete, although we attempted to collect data from all 30 patients. Based on our clinical practice, if the granuloma caused by spirocercosis did not cause an obstruction in the esophagus, we always recommended conservative treatment. Until the middle of the examined time period, this included imidacloprid/moxidectin-containing spot-on products, milbemycin oxime-containing tablets, ivermectin injection, or a combination of the above. In the last four years, from 2013, based on the standard international recommendations (Lobetti 2013), our recommended therapy was modified to doramectin injections. The owners were informed about the risks of the product's off-label use, and examination of MDR1gene mutation was recommended along with trial therapy. Some literature resources claim disophenol to be the only confirmed adulticide drug, but it does not affect juvenile worms and is not available on the market (Lobetti 2013). Other sources claim that macrocyclic lactones are an effective treatment for benign esophageal alterations caused by Spirocerca lupi (Berry 2000, Lavy et al. 2002, Kelly et al. 2008, Lobetti 2012, Austin et al. 2013), while effective prevention is possible with avermectins, milbemycin and moxidectin (Lavy et al. 2003, Kelly et al. 2008, Kok et al. 2010, 2011, Le Sueur et al. 2010, Nolan et al. 2012). In our experience, doramectin-treated patients become symptomfree, but use of the drug is greatly hindered by off-label application and the risk of complications. There is no registered drug for the treatment of canine spirocercosis on the Hungarian market, but Advocate ${ }^{\circledR}$ spot-on (Bayer, Germany), containing a combination of imidacloprid and moxidectin, is registered for prevention of spirocercosis in dogs. Based on literature data, it is $100 \%$ effective in preventing Spirocerca lupi-induced esophageal granulomas in dogs. In experimentally infected dogs it was also effective against adult Spirocerca lupi forms in $98.5 \%$ of cases, without the patients showing adverse effects, when applied weekly for 19 weeks (Austin et al. 2013). The efficacy of Advocate spot-on should therefore also be examined in a clinical case load.

\section{Conclusions}

Based on our research, we can clearly show a significant increase in spirocercosis diagnoses among patients arriving for gastroscopy at ELUVMBP between January 1, 2007 and September 30, 2016 and this disease is prevalent at any time of year. Historically, and in our experience, doramectin has been shown to be effective in the treatment of spirocercosis, but since licensed treatment options are now available, a combination of moxidectin/imidacloprid should be used. In addition, preventative measures should be considered in high-risk situations.

\section{Acknowledgements}

We would like to thank Péter Fehérvári, a colleague in the Department of Biomathematics and Informatics at the University of Veterinary Medicine, for helping to create the figures, and Zoltán Bende and Zoltán Vári, both veterinarians, for their help in data collection. 


\section{Conflict of interest}

The authors declare that they have no competing interests. Zoltán Lukács is an employee of Bayer Hungária Kft.

\section{Ethical standards}

All applicable international and institutional guidelines for the care and use of animals were followed.

\section{References}

Aroch I, Markovics A, Mazaki-Tovi M, Kuzi S, Harrus S, Yas E, Baneth G, Bar-EI M, Bdolah-Abram T, Segev G, Lavy E (2015) Spirocercosis in dogs in Israel: A retrospective case-control study (2004-2009). Vet Parasitol 211: 234-240

Austin CM, Kok DJ, Crafford D, Schaper R (2013) The efficacy of a topically applied imidacloprid $10 \%$ / moxidectin $2.5 \%$ formulation (Advocate ${ }^{\circledR}$, Advantage ${ }^{\circledR}$ Multi, Bayer) against immature and adult Spirocerca lupi worms in experimentally infected dogs. Parasitol Res 112: 91-108

Bailey WS (1963) Parasites and cancer: Sarcoma in dogs associated with Spirocerca lupi. Ann NY Acad Sci 108: $890-923$

Berry WL (2000) Spirocerca lupi esophageal granulomas in 7 dogs: resolution after treatment with doramectin. J Vet Intern Med 14: 609-612

Beugnet F, Crafford D, de Vos C, Kok D, Larsen D, Fourie $J$ (2016) Evaluation of the efficacy of monthly oral administration of afoxolaner plus milbemycin oxime (NexGard Spectra ${ }^{\circledR}$, Merial) in the prevention of adult Spirocerca lupi establishment in experimentally infected dogs. Vet Parasitol 226: $150-161$

Bokori J (1956) Spirocerca lupi okozta féregcsomók miatt létrejött nyelőcsőszủkület és következményes gyomorkitágulás kutyában. Magy Állatorv Lapja 11: 189-190

Brodey RS, Thomson RG, Sayer PD, Eugster B (1977) Spirocerca lupi infection in dogs in Kenya. Vet Parasitol 3: 49-59

Chitwood BG (1934) The status of Spirocerca sanguinola (Rudolphi, 1819) Seurat, 1913. J Parasitol 20: 69

Evans, LB (1983) Clinical diagnosis of Spirocerca lupi infestation in dogs. J S Afr Vet Assoc 54: 189-191

Fitzsimmons WB (1960) Observations on the incidence, pathology and aetiology of Spirocerca lupi infestation in Nyasaland. Brit Vet J 116: 272-275

\section{Open access}

This article is distributed under the terms of the Creative Commons Attribution 4.0 International License (http://creativecommons.org/licenses/ by/4.0/), which permits unrestricted use, distribution and reproduction in any medium, provided you give appropriate credit to the original author(s) and the source, provide a link to the Creative Commons license, and indicate if changes were made.

Kassai T (2011) Kutyák nyelőcsőférgessége-Spirocercosis. In: Kassai T (ed) Helmintológia 2nd edn. MÁOK, Budapest, pp 183-184

Kelly PJ, Fisher M, Lucas H, Krecek RC (2008) Treatment of esophageal spirocercosis with milbemycin oxime. Vet Parasitol 156: $358-360$

Kok DJ, Williams EJ, Schenker R, Archer NJ, Horak IG (2010) The use of milbemycin oxime in a prophylactic anthelmintic programme to protect puppies, raised in an endemic area, against infection with Spirocerca lupi. Vet Parasitol 174: $277-284$

Kok DJ, Schenker R, Archer NJ, Horak IG, Swart P (2011) The efficacy of milbemycin oxime against pre-adult Spirocerca lupi in experimentally infected dogs. Vet Parasitol 177: $111-118$

Lavy E, Aroch I, Bark H, Markovics A, Aizenberg I, MazakiTovi M, Hagag A, Harrus S (2002) Evaluation of doramectin for the treatment of experimental canine spirocercosis. Vet Parasitol 109: 65-73

Lavy E, Harrus S, Mazaki-Tovi M, Bark H, Markovics A, Hagag A, Aizenberg I, Aroch I (2003) Spirocerca lupi in dogs: prophylactic effect of doramectin. Res Vet Sci 75: 217-222

Le Sueur C, Bour S, Schaper, R (2010) Efficacy of a combination of imidacloprid $10 \% /$ moxidectin $2.5 \%$ spot-on (Advocate ${ }^{\circledR}$ for dogs) in the prevention of canine spirocercosis (Spirocerca lupi). Parasitol Res 107: 1463-1469

Lobetti R (2000) Survey of the incidence, diagnosis, clinical manifestations and treatment of Spirocerca lupi in South Africa. J S Afr Vet Assoc 71: 43-46

Lobetti R (2012) Successful resolution of oesophageal spirocercosis in 20 dogs following daily treatment with oral doramectin. Vet J 193: 277-278 
Lobetti R (2013) Spirocercosis. In: Washabau RJ (ed), Day MJ (ed) Canine and feline gastroenterology, Elsevier Saunders, St. Luis pp 583-586

Mazaki-Tovi M, Baneth G, Aroch I, Harrus S, Kass PH, Ben-Ari T, Zur G, Aizenberg I, Bark H, Lavy E (2002) Canine spirocercosis: clinical, diagnostic, pathologic, and epidemiologic characteristics. Vet Parasitol 107: 235-250

Mylonakis ME, Koutinas AF, Liapi MV, Saridomichelakis MN, Rallis TS (2001) A comparison of the prevalence of Spirocerca lupi in three groups of dogs with different life and hunting styles. J Helminthol 75: 359-361

Mylonakis ME, Rallis TS, Koutinas AF, Ververidis HN, Fytianou A (2004) A comparison between ethanol-induced chemical ablation and ivermectin plus prednisolone in the treatment of symptomatic esophageal spirocercosis in the dog: a prospective study on 14 natural cases. Vet Parasitol 120: $131-138$

Nolan TJ, Lok JB (2012) Macrocyclic lactones in the treatment and control of parasitism in small companion animals. Curr Pharm Biotechnol 13: 1078-1094
Ranen E, Lavy E, Aizenberg I, Perl S, Harrus S (2004) Spirocercosis-associated esophageal sarcomas in dogs. A retrospective study of 17 cases (1997-2003). Vet Parasitol 119: $209-221$

Schroeder H, Berry VL (1998) Salivary gland necrosis in dogs: a retrospective study of 19 cases. J Small Anim Pract 39: $121-125$

Széll Z, Máthé Á, Erdélyi I, Deim Z, Bende Z, Varga I (2001) Spirocercosis és alariosis-két ritka helminthosis kutyákban. Rövid irodalmi áttekintés és két eset ismertetése. Magy Állatorv Lapja 123: 421-428

Willard MD (2013) Esophageal neoplasia. In: Washabau RJ, Day MJ (eds) Canine and feline gastroenterology, Elsevier Saunders, St. Louis pp 595-598 
